UDC 37:001.895

DOI: 10.31470/2415-3729-2019-9-09-22

\title{
Impact of Training Through Research on the Evolution of Contemporary Teaching Technology
}

\section{Eduard Coropceanu}

Doctor, Professor,

Rector Tiraspol State University, Republic of Moldova,

$\triangle$ Strada Drumul Viilor 26A, Chisinau, 2069

E-mail: ecoropceanu@yahoo.com

Date of receipt of the article: December 03, 2018

Article accepted for publication: February 21, 2019

\section{Вплив навчання через дослідження на еволюцію порівняльних педагогічних технологій}

\section{Едуард Коропчеану}

Доктор, професор,

Ректор Тираспольського державного університету,

Молдова,

$\triangle$ Strada Drumul Viilor 26A, Кишинев, 2069

E-mail: ecoropceanu@yahoo.com

Дата надходження статті: 03 грудня 2018 р. Стаття прийнята до друку: 21 лютого 2019 р.

\section{Abstract}

The orientation of the education system towards technologies based on training through research presents an objective not only educational, but also socio-economic, because the challenges of the future society are largely related to the elaboration of new materials, more efficient ones than the existing analogies. The educational system has the task of developing competencies from the first steps to the university level: research, education, and entrepreneurship. In order to achieve this goal, it is necessary to develop evolutionary strategies from traditional 
to innovative education, with the application of developed products in different fields, in order to generate performant and ergonomic technologies.

It is important for the scientific study to have relevant goals by applying the obtained results in order to solve real problems in everyday life, agriculture, material science, etc. As a model, it is proposed to study the synthesis process of coordinating compounds, analysis of composition, structure and determination of the practical application domains based on the manifested biological and physical properties.

For the university level, as an exercise in the research competence, it is proposed to obtain and analyze some coordinating compounds based on transition metals. In order to achieve multi-level interdisciplinary studies, the starting point is the interaction of simple salts and organic ligands that lead to highly complex chemical compounds, composition study, molecular structure, and practical implementation based on useful properties.

An important role in the manifestation of the properties of metallo-complexes is also played by the ligands in their composition which, due to the large set of donor atoms, create stable complexes different in composition, structure and properties with transition metal ions. Biologically active substances included in the complexes of metals as ligands substantially increase their effectiveness.

After developing the research competence which results in the students synthesizing to assemble new coordinating compounds, it is necessary to move from the oriented, guided synthesis stage to that of creating new molecular models based on their own ideas. At this level it becomes obvious the manifestation of creativity and the spirit of initiative which can end with the development of innovation competence - the supreme product of the educational process, which offers the future specialists the freedom of creation, the independence and the confidence in their own orientation skills in the issues regarding the professional field.

Key words: training through research, interdisciplinary study, innovation, entrepreneurship. 


\section{References}

1. Staver, N., Budeci, A. \& Chicu, D., Coropceanu, E. (2016). Rolul tehnologiilor informaţionale în îmbunătăţirea motivaţiei elevilor de a studia chimia. Univers pedagogic. 3(51), pp. 50-54.

2. Nicolescu, B. (1999). Transdisciplinaritatea(manifest). Iai: Polirom.

3. Bejenari, T., Frumusachi, S., Calmuchi, L. \& Coropceanu, E., (2015). Dezvoltarea elementelor de transdisciplinaritate în cadrul predării-învăării chimiei i biologiei. Chişinău: UST. 238 pag.

4. Codreanu, S., Arsene, I. \& Coropceanu, E. (2017). Utilizarea unor modalităi moderne de calcule cuantochimice a stării energiei sistemelor moleculare în cursul de chimie. Acta et commentationes. Nr. 1, pp. 147-156.

5. Coropceanu, E., Bologa, O., Arsene, I., Vitiu, A., Bulhac, I., Gorinchioy, N. \& Bourosh, P. (2016). Synthesis and Characterization of Inner-Sphere Substitution Products in Azide-Containing Cobalt (III) Dioximates. Russ. Journ. Coord. Chem. V. 42. N. 8, pp. 516-538.

6. Coropceanu, E. \& Chicu, D. (2015). Cercetarea - factor de integrare a ştiinţei şi motivare pentru instruire. Univers pedagogic. N3 (47), pp. 27-33.

7. Calalb, M. (2017). Pedagogia învăţării prin investigaţie şi impactul ei asupra deprinderilor de cercetare ştiinţifică şi învăţare pe tot parcursul vieţii. Studia universitatis moldaviae. Seria tiine ale Educaiei. N. 5(105), pp. 32-39.

8. Croitor, L., Coropceanu, E., Masunov, A., Rivera-Jacquez, H.J., Siminel, A., Zelentsov, V., Datsko, T. \& Fonari, M., (2014). Polymeric Luminescent $\mathrm{Zn}$ (II) and Cd (II) Dicarboxylates Decorated by Oxime Ligands: Tuning the Dimensionality and Adsorption Capacity. Crystal Growth \& Design. V. 14, pp. 3935-3948.

9. Coropceanu, E., Croitor, L., Siminel, A., Chumakov, Yu., \& Fonari, M., (2016). The Luminescence Attenuation in the Solid State by Fluoride Anion Entrapped in the OneDimensional Zn (II) Dioximate and Mononuclear Cd (II) Dioxime. Polyhedron. V. 109, pp. 107-114. 
10. Coropceanu, E., Rija, A., Lozan, V., Bulhac, I., Duca, Gh., Kravtsov, V. \& Bourosh, P., 2016. Discrete Binuclear Cobalt (III) Bis-dioximates with Wheel-and-Axle Topology as Building Blocks To Afford Porous Supramolecular Metal-Organic Frameworks. Crystal Growth \& Design. V. 16, pp. 814-820.

11. Bourosh, P.N., Coropceanu, E.B., Ciloci, A.A., Clapco, S.F., Bologa, O.A., Bivol, C.M., Tiurina, J.P. \& Bulhac, I. (2013). New Co (III) Dioximates with Hexafluorophosphate Ion as Stimulators of the Proteolytic Activity of the Micromycete Fusarium gibbosum CNMN FD 12. Russ. Journ. Coord. Chem. V. 39. N. 11, pp. 777786.

12. Coropceanu, E.B., Bulhac, I., Shtefyrtse, A.A., Botnar', V.F., Melenchuk, M., Kuligin, E. \& Bourosh, P.N. (2017). Synthesis, Crystal Structure, and Biological Properties of the Complex $\left[\mathrm{Co}(\mathrm{DmgH})_{2}(\mathrm{Seu})_{1.4}(\mathrm{Se}-\mathrm{Seu})_{0.5}\left(\mathrm{Se}_{2}\right)_{0.1}\right]$ $\left[\mathrm{BF}_{4}\right]$. Russ. Journ. Coord. Chem. V. 43. N. 3, pp. 164-171.

13. Codreanu, S., Arsene, I., \& Coropceanu, E. (2018). The development of research competence based on quantum calculation of molecular systems. Social Sciences and Education Research Review. V. 5. N. 1, pp. 95-109.

14. Coropceanu, E., Rija, A., Arsene, I., \& Putină, M. (2014). Dezvoltarea abilităilor de autoformare la chimie în baza unor tehnologii informaionale. Studia universitatis moldaviae. Seria tiine ale Educaiei. N. 9(79), pp. 92-98.

15. Placinta, D. \& Coropceanu, E. (2018). Valorificarea instrumentelor TIC în dezvoltarea competenei de investigare a proceselor biologice la liceeni. Studia universitatis moldaviae. Seria tiine ale Educaiei. N. 5 (115), pp. 98-106.

\section{Introduction}

In the context of the depletion of natural resources in contemporary society, there is an increasing need to determine solutions that would ensure sustainable development grounded on new ergonomic technologies based on more efficient 
materials. Elaboration of new creative materials and advanced technologies requires creative and innovative thinking, so the contemporary educational system has the task of cultivating the research competence and the development of new original ideas from the earliest age. One of the most effective methods of developing and practicing the innovative capacity is training through research. The fundamental problem is the lack of a clear methodology of training through research. In addition, each domain has its own specificity and requires an individual approach. Training through research usually has an interdisciplinary character. A positive effect on promoting these ideas at pre-university level are held by a number of contemporary methods such as training through discovery, training based on research projects, etc.

It is necesary that the educational policies to guide the curriculum and the contents in the direction of application, practical use of acquired knowledge to practice experimental skills and then proceed to the next stage - the creative development of new ideas based on known models.

The transition from informative education to the formative one is difficult for several reasons: lack of teaching methodology for teacher training in the key to training through research; lack of methodological support; the modest material conditions of institutions, etc., which often do not allow some activities to be carried out at the necessary level. However, the teaching community is looking for ways to connect the training process to the current needs. These solutions may be different, depending on the subject/domain specificity (Staver, Budeci, Chicus, Coropceanu, 2016: 50-54)

It is very important for the training process through research to be captivating, inter- and trans-disciplinary. Involvement of different study methods to highlight different aspects of the problem emphasizes the individuality and importance of each research method.Theyhelp not only to explore the different aspects of the problem, but also allow a deep study and conclusions to be drawn from the studied phenomenon/body (Nicolescu, 1999; Bejenari, Frumusachi, Calmuțchi, Coropceanu, 2015; Codreanu, Arsene, Coropceanu, 2017; Coropceanu, 
Bologa, Arsene, Vitiu, Bulhac, Gorinchioy, Bourosh, 2016.: 516-538).

Chemistry, being a discipline at the boundary between Biology and Physics, has different tangencies with the two domains, in the overlapping regions generating new interdisciplinary sciences: Bio-Chemistry, Agro-Chemistry, Physical Chemistry, Quantum Chemistry, Crystalo-Chemistry, etc. In the last decades there is an interpenetration between the branches of Chemistry (Inorganic Chemistry and Organic Chemistry, etc.), which allows the emergence of new domains (Metalo-Organic, Bio-Organic Chemistry, etc.) that meet classes of new compounds with special structure and properties. This inter-disciplinary «hybridization» allows the development of new materials, which exhibit non-trivial properties, which will generate new high performance technologies.

It is important for the scientific study to have relevant goals by applying the obtained results in order to solve real problems in everyday life, agriculture, material science, etc. As a model, it is proposed to study the synthesis process of coordinating compounds, analysis of composition, structure and determination of the practical application domains based on the manifested biological and physical properties. As a result of the exercise and development of the research competence, the aim is the formation of innovative and entrepreneurial competence which would allow the development of new original solutions and their practical implementation in order to increase the efficiency of some economic processes based on the new materials (Coropceanu, 2015: 27-33; Calalb, 2017: 32-39).

\section{Results and discussions}

To rationally implement training through research there are a number of questions that arise: At what level of education is necessary to develop the research competence? How can research be carried out at different stages of personality development? What methods are welcomed at different levels of the education system? What mechanisms can be used to stimulate active involvement in training through research?

A rational solution for motivating training is interdisciplinary study, which has a decisive importance in the 
development of research competence, as it allows the integrated approach of some processes. The dual programs of initial training of young specialists at the university (Biology and Chemistry, Geography and History, Mathematics and Computer Science, etc.) ensure the development in an inter-disciplinary context which offers the graduates a number of advantages in the field of complex studies, employment in the field work, analysis of complicated phenomena, etc. The involvement of students in scientific research and/or institutional, national and international projects presents agenuine experience in the inter-disciplinary professional development.

An inter-disciplinary study has to involve different aspects: from the initial stages, problem formulation, identifying the need for research, formulation of goals, to practical activities, implementation of results in various fields of the economy, and formulation of conclusions on future development directions of research. As an example we can study the identification of problems related to the needs of some branches such as MicroBiology, Agriculture etc. in chemical compounds with stimulating activity for physiological processes. The composition and molecular structure of chemical compounds may have a different influence on living organisms.

For Chemistry there can be proposed several models that would allow the fulfillment of complex studies of molecular characteristics, chemical processes and allow the pupil/student to go from simple substances $\rightarrow$ the synthesis of complex systems analysis of composition and structure based on physical and chemical methods $\rightarrow$ calculation of molecular energy, determination of substitution or condensation possibilities in some functional groups $\rightarrow$ determination of useful properties and practical application domains.

In the study of the Chemistry discipline, the investigation contributes to the knowledge of the phenomena and processes arising in the analyzed systems, the direction of the occurrence of one or another reaction, the composition of the substances and others through laboratory work, different experiences and other interactive methods. Investigational competence of pupils begins to be formed from the moment they first make observations about 
processes, phenomena that flow into the surrounding world. The further development of competence continues through the use of various strategies and didactic activities is planned and conducted by the teacher. Investigation can be complemented by new digital applications that can be used in laboratory work in chemistry, which would lead to student motivation and a better understanding of the processes and phenomena arising in the investigated chemical systems. In this case, digital sets of sensors of the digital lab can be applied as digital didactic tools (Placinta, Coropceanu, 2018: 98-106). With their help, investigative competence in Chemistry can be placed on a new stage of development motivating both pupils and teachers. The sensors allow the development of a series of experimental activities with the direct involvement of pupils, such as: electricity generation, ions in solution, endothermic and exothermic reactions, combustion, acid rain, flame temperature determination, gas solubility, strong acid titration with a strong base, colour absorption, etc.

For the university level, as an exercise in the research competence, it is proposed to obtain and analyze some coordinating compounds based on transition metals. In order to achieve multi-level interdisciplinary studies, the starting point is the interaction of simple salts and organic ligands that lead to highly complex chemical compounds, composition study, molecular structure, and practical implementation based on useful properties.

The algorithm of these investigations should evolve from the initial stages of synthesis of organic ligands (in the case of new coordinating agents) obtaining coordinating compounds up to studying useful properties and identifying practical application areas. The set of methods used in the research in the fields of Chemistry, Physics and Biology allows the researcher to integrate the knowledge from these areas and to get a clear picture of the processes being carried out. It is important to emphasize the need to realize the importance of the composition-structure-property correlation in order to ensure the positive evolution of the creative process while respecting the ergonomic aspect of the idea. 
As a result of the synthesis and the study of the properties of a series of coordinating compounds it was established that, depending on composition and structure, the analyzed compounds exhibit luminescent properties (Croitor, Coropceanu, Masunov, Rivera-Jacquez, Siminel, Zelentsov, Datsko, Fonari, 2014: 39353948; Coropceanu,Croitor, Siminel, Chumakov, Fonari, 2016: 107-114) or properties of porous materials with adsorbent properties (Coropceanu, Rija, Lozan, Bulhac, Duca, Kravtsov, Bourosh, 2016: 814-820), stimulation of physiological processes in microorganisms and higher crop plants (Bourosh, Coropceanu, Ciloci, Clapco, Bologa, Bivol, Tiurina, Bulhac, 2013: 777-786; Coropceanu, Bulhac, Shtefyrtse, Botnar', Melenchuk, Kuligin, Bourosh, 2017: 164-171), inhibiting corrosion processes of steels in water in the aqueduct, etc. The application of contemporary study methods allows a profound analysis and the achievement of scientific results that can be patented and published in international impact journals, which has a positive influence on the career development of young researchers.

The biological properties of metalo-complexes in large part can be attributed to the presence of the metals $\mathrm{Fe}, \mathrm{Cu}, \mathrm{Mo}, \mathrm{Co}$, $\mathrm{Zn}, \mathrm{Mn}, \mathrm{Ni}$, etc., which present microelements directly related to atoms and groups of atoms in the molecules of organic substances. These elements, coming in very small amounts in the cells, play an important role in their vital activity. The multilateral influence of microelements is important by their participation in the fine reactions of cellular exchange of substances, especially in fermentative processes. Copper, zinc, cobalt, manganese, molybdenum, calcium, iron participate in oxidative reduction processes that occur in vegetal and animal organisms, are part of a series of important oxidative ferments, participate in carbohydrate and protein metabolism in organisms. Microelements, especially the bio-metals such as cobalt, copper, zinc, manganese, participate in the formation or activation of ferments, vitamins, hormones, regulate the exchange of substances, causing growth, development, multiplication, productivity and quality of production. The ability of the metal ion to form the active center of the ferment depends on the metal ion coordination capacity, the geometry and the stability of the formed complex. 
An important role in the manifestation of the properties of metallo-complexes is also played by the ligands in their composition which, due to the large set of donor atoms, create stable complexes different in composition, structure and properties with transition metal ions. Biologically active substances included in the complexes of metals as ligands substantially increase their effectiveness.

The use of coordinating compounds to stimulate physiological processes in fungi is justified by several causes: due to their structure the metallo-complexes are similar to natural biological complexes that are regulators of the vital functions of organisms (nature itself has evaluated the value of bio-macromolecules to perform vital functions for organisms); in most complex generating metallo-complexes we find biometals irreplaceable biological catalysts, the action of which is related to proteins and specific ferments; the ligands in the coordinating compounds may present molecules with biological properties, etc.

After developing the research competence which results in the students synthesizing to assemble new coordinating compounds, it is necessary to move from the oriented, guided synthesis stage to that of creating new molecular models based on their own ideas. At this level it becomes obvious the manifestation of creativity and the spirit of initiative which can end with the development of innovation competence - the supreme product of the educational process, which offers the future specialists the freedom of creation, the independence and the confidence in their own orientation skills in the issues regarding the professional field.

However, in order for the creative work to be useful, to bring benefits to the researcher and society, it is necessary to develop an entrepreneurial competence in parallel so that the new materials and technologies are oriented to solving real problems a trend that becomes more and more obvious at the global level.

In order for the results of training through research altogether with the development of innovation and entrepreneurial competences to bring about economic effects, it is necessary a State policy of co-interesting the real sector of the 
economy to cooperate with the field of research and innovation for the implementation of the best elaboration in different fields. This is a process that may contribute to both parties benefit and building a prosperous society.

The interdisciplinary teaching-learning process in Chemistry is an important and determinant factor for the achievement of a modern and formative education. Interdisciplinary study of content from different educational disciplines will contribute substantially to the formation and development of Chemistry-specific skills, logical and flexible thinking, to a better fixation and systematization of the theoretical knowledge and the ability to apply in practice in different fields. Developing different motivation mechanisms for training is an important objective of contemporary didactics in the field of exact sciences and of nature. In order to increase pupils/students' motivation for the study of Chemistry, effective models of integration of the Education-Research-Practical Application areas are required. For this purpose, it is proposed to use integrated ICT with various Chemistry-specific programs, applications and software that would allow the calculation of molecular energy, chemical processes in the analyzed systems, visualization of the structure, determination of some environmental factors and others which requirean interdisciplinary approach of knowledge, skills and abilities in the field of Chemistry in particular, as well as in Mathematics, Informatics, Physics (Codreanu, Arsene, Coropceanu, 2018: 95-109; Coropceanu, Rija, Arsene, Putină, 2014: 92-98).

To increase the inter- and trans-disciplinary character of the studies with the connection between research and training, a series of actions are necessary to be carried out:

- Providing the material basis to comply with the needs of inter- and trans-disciplinary studies;

- Creating training opportunities for teaching staff in general education in order to prepare them for the organization and conduct of research activities;

- Elaboration of the methodology for transition from disciplinary tasks to inter- and trans-disciplinary;

- Identification of the elaboration possibilities of the tasks for knowledge integration; 
- Promoting multi-dimensional research and encouraging the diversification of scientific research;

- Involving students and teachers in solving real or artificial problems of an inter- or trans-disciplinary nature;

- Establishing stronger links between general education, higher education and research;

- Creation of joint research teams made up of PhD students, master students, undergraduates and pupils for joint studies;

- Stimulating the cultivation of innovative qualities in pupils and participation in various competitions for presenting innovations (Best Innovative Pupil, etc.);

- Creating opportunities for training young people in the field of initiating and administering a research or business to facilitate the process of integration into the labour market.

\section{Conclusions}

Training through research calls for a fundamental review of the educational paradigm transferring the focus from the informative education onto the formative one developing the individual creative potential. Based on the research competence it is necessary to form the innovative and entrepreneurial skills for the educational system to provide the society with personalities able to integrate organically into the labor market.

\section{Коропчеану E.}

\section{Вплив навчання через дослідження на еволюцію сучасних педагогічних технологій}

\section{Анотація}

Орієнтація системи освіти на технології, що грунтуються на навчанні через дослідження, $\epsilon$ метою не тільки освітньої, але й соціально-економічної, оскільки виклики майбутнього суспільства значною мірою пов'язані 3 розробкою нових матеріалів, більш ефективними, ніж існуючі аналогії . Завдання системи освіти - розвиток компетенцій від перших кроків до університетського рівня: дослідження, освіта та підприємництво. Для досягнення цієї 
мети необхідно розробити еволюційні стратегії від традиційної до інноваційної освіти, із застосуванням розроблених продуктів у різних галузях з метою створення ефективних та ергономічних технологій.

Важливо, щоб наукові дослідження мали відповідні цілі шляхом застосування отриманих результатів для вирішення реальних проблем у повсякденному житті, сільському господарстві, матеріалознавстві тощо. В якості моделі пропонується вивчити процес синтезу координаційних сполук, аналіз складу, структури та визначення доменів практичного застосування на основі виявлених біологічних та фізичних властивостей.

Для університетського рівня, як завдання в науковій компетенції, пропонується отримати і проаналізувати деякі координаційні сполуки на основі перехідних металів. Для досягнення багаторівневих міждисциплінарних досліджень відправною точкою є взаємодія простих солей і органічних лігандів, які призводять до складних хімічних сполук, вивчення складу, молекулярної структури та практичної реалізації на основі корисних властивостей.

Важливу роль у прояві властивостей металокомплексів відіграють також ліганди в їх складі, які завдяки великому набору донорних атомів створюють стійкі комплекси, різні за складом, структурою та властивостями 3 іонами перехідних металів. Біологічно активні речовини, що входять до складу комплексів металів як ліганди, істотно підвищують ї ефективність.

Після розробки дослідницької компетенції, результатом якої $\epsilon$ узагальнення студентів для збирання нових координаційних сполук, необхідно перейти від орієнтованого, керованого етапу синтезу до створення нових молекулярних моделей на основі власних ідей. На цьому рівні стає очевидним прояв творчості і дух ініціативи, який може закінчитися розвитком інноваційної компетентності вищим продуктом навчального процесу, який пропонує майбутнім фахівцям свободу створення, незалежності i впевненості в своїх власні орієнтаційні навички з питань професійної сфери. 
Ключові слова: навчання через дослідження, міждисциплінарне дослідження, інновації, підприємництво.

\section{Коропчеану Э.}

\section{Влияние обучения через исследование на эволюцию современных педагогических технологий}

\section{Аннотация}

Ориентация системы образования на технологии, основанные на обучении посредством исследований, представляет собой не только образовательную, но и социально-экономическую цель, поскольку проблемы будущего общества в значительной степени связаны с разработкой новых материалов, более эффективных, чем существующие аналогии. Задачей образовательной системы является развитие компетенций от первых шагов до университетского уровня: исследования, образование и предпринимательство. Для достижения этой цели необходимо разработать эволюционные стратегии от традиционного до инновационного образования с применением разработанных продуктов в различных областях, с тем чтобы создавать эффективные и эргономичные технологии.

Ключевые слова: обучение через исследование, междисциплинарное исследование, инновации, предпринимательство. 